http://jmscr.igmpublication.org/home/ ISSN (e)-2347-176x ISSN (p) 2455-0450 crossref DOI: https://dx.doi.org/10.18535/jmscr/v7i10.133

\title{
Observational Study on Conversion of Laparoscopic Cholecystectomy to Open Cholecystectomy and Its Causes
}

\author{
Authors \\ Gopikrishna D, Sarath Chandran S, Ashwin Muthukumar R, Suresh Kumar R \\ Department of General Surgery, Rajah Muthiah Medical College, Chidambaram
}

\begin{abstract}
Introduction: Minimal invasive surgery has largely replaced conventional open procedures to large extent, one such case is Cholecystectomy and has become gold standard procedure of choice for Cholecystectomy and this study aims to study the rate and causes of conversion of laparoscopic Cholecystectomy into open Cholecystectomy.

Materials and Methods: A prospective non randomized observational study was done on 50 consenting patients undergoing laparoscopic Cholecystectomy in Department of General Surgery in Rajah Muthaiah Medical College, Chidambaram from June 2016 to June 2019. Patients are selected on the basis of purposive sampling method after fulfilling the inclusion and exclusion criteria.

Results: Out of 50 patients included in the study. Most common age group requiring laparoscopic Cholecystectomy is 30 to 50 years and females were found to be $80 \%$ of the targeted sample. Higher BMI and emergency laparoscopic intervention resulted in higher conservion rate of 50\% and $100 \%$ respectively. Chronic disease like diabetes in both open and Laparoscopic group was found to be $50 \%$ and hypertensive was found to be $50 \%$ and $4.2 \%$.

In setting of acute cholecystitis and CBD calculus conversion rate was found to be $6 \%$ and $100 \%$ respectively. Incidence of complications was $50 \%$ in the converted group compared to $4.2 \%$ in Laparoscopic Cholecystectomy

Conclusion: In our study we conclude that, in acute disease conversion rate is high, presence of adhesions and inflammation intraoperatively is a key factor. The rate of conversion and bile stone spillage is proportional to the severity of disease.

Keywords: Open Cholecystectomy, Gallstones, Laparoscopic Cholecystectomy, CBD stones, Acute cholecystitis.
\end{abstract}

\section{Introduction}

In era of minimal invasive surgery, laparoscopic Cholecystectomy played a important role in popularising and replacing conventional open Cholecystectomy procedures. Now Laparoscopic Cholecystectomy is the procedure of choice for gallbladder disease compared to open Cholecystectomy.
Gall stone disease is a frequently occuring disease in India, although most cases are asymptomatic, still gall stones disease contribute substantially to health care costs and it's complications are life threatening. Laparoscopic Cholecystectomy is universally adopted due to appeal of diminished pain and fatigue, early return to normal activities and superior cosmesis had made it gold standard. 
Approximately $75 \%$ of all Cholecystectomies are preformed laparoscopically and conversion to open procedure ranges from $5 \%$ to $10 \%$ worldwide. The National In of health postulated that the outcome of Laparoscopic Cholecystectomies would be greatly influenced by surgeon specific factors such as training, experience, skill and judgement. In addition, numerous patient and disease related factor such as male gender, obesity, old age ( $>65$ years), prior abdominal surgery, acute Cholecystitis and anamolous anatomy have been reported as significant risk factors for conversion of Laparoscopic to open procedures.

The study aims at observing these factors and identifying the conversation rate and factors causing the conversion.

\section{Materials and Methods}

A non randomized prospective observational study conducted in Department of General surgery in Rajah Muthiah Medical College, between the period of June 2016 to June 2019 and patients are selected on purposive sampling method based on the inclusion and exclusion criteria were included in the study. Patients included in the study of after obtaining consent and detailed history, general physical examination and neurological examination. Routine investigations such as complete hemogram, TLC, DLC, ESR, FBS, RFT and LFT and other investigations such as ECG, Chest X-ray etc are done.

Among these patients conversion of Laparoscopic procedure into open procedure were evaluated and following data such as intraoperative findings like adhesions, excessive bleeding, any untoward event if present were included and collected data is analysed and compiled.

\section{Results and Discussion}

The findings of the study are:

Most common age group that is involved in gall stone disease requiring surgical intervention is 30 to 50 years around $80 \%$ and females $62 \%$. Higher
BMI had a higher rate of conversion around $50 \%$. $100 \%$ of the emergency cases need conversion. In the present study, $68 \%$ of cases were done for the symptomatic gall stone. The two cases which required conversion were for post ERCP and acute cholecystitis. Both cases had severe adhesions intra-operatively.

All cases in our stud had right upper quadrant pain at least once in their lifetime, only $14 \%$ in laparoscopic group and $50 \%$ in converted group had fever.

Both cases were diabetic in the converted group as compared to none in the non converted group, $50 \%$ were hypertensives in the converted group as compared to $4.2 \%$. In the non converted group.

Intra operative complications like omental adhesions, perforation, inflammation, bleeding, bile leak were seen in $50 \%$ converted cases as compared to $29.2 \%, 18.8 \%, 18.8 \%, 22.9 \%, 27.1 \%$ in the non converted group.

$6 \%$ of the acute cholecystitis (1 of 17) needed conversion and $100 \%$ of those who showed a CBD calculus needed conversion.

In $22 \%$ there was spillage of stones in laparoscopic group as compared to $50 \%$ in the open group, this spillage occurred prior to conversion.

The incidence of complications were $50 \%$ in the converted group compared to $4.2 \%$ in laparoscopic group.

Table 1: Age Distribution

\begin{tabular}{|l|c|c|}
\hline Age & Laparoscopic & $\begin{array}{c}\text { Laparoscopic converted } \\
\text { to open }\end{array}$ \\
\hline less than 30 & 1 & 0 \\
\hline 30-40 years & 22 & 1 \\
\hline 41-50 years & 17 & 0 \\
\hline 51-60 years & 6 & 0 \\
\hline more than 60 years & 1 & 1 \\
\hline
\end{tabular}

Table 2: BMI

\begin{tabular}{|l|c|c|c|}
\hline SURGERY & BMI $\left(\mathbf{k g} / \mathbf{m}^{\mathbf{2}}\right)$ & Frequency & Percent \\
\hline \multirow{3}{*}{ Laparoscopic } & $19-24.9$ & 47 & 97.9 \\
\cline { 2 - 4 } & $25-29.9$ & 1 & 2.1 \\
\cline { 2 - 4 } & Total & 48 & 100 \\
\hline \multirow{2}{*}{$\begin{array}{l}\text { Laparoscopic } \\
\text { converted to open }\end{array}$} & $>30$ & 1 & 50 \\
\cline { 2 - 4 } & $19-24.9$ & 1 & 50 \\
\cline { 2 - 4 } & Total & 2 & 100 \\
\hline
\end{tabular}


Table 3: Distribution of Pathology of Cases

\begin{tabular}{|l|c|c|}
\hline Diagnosis & Laparoscopic & $\begin{array}{c}\text { Laparoscopic } \\
\text { converted to open }\end{array}$ \\
\hline Stones & 34 & 0 \\
\hline Polyp & 2 & 0 \\
\hline $\begin{array}{l}\text { Chronic } \\
\text { cholecystistis }\end{array}$ & 12 & 0 \\
\hline Post ERCP & 0 & 1 \\
\hline Acute cholecystitis & 0 & 1 \\
\hline
\end{tabular}

In our study $68 \%$ of cases were done for symptomatic gall stones the two cases which required conversion were these for post ERCP and acute cholecystitis both cases had severe adhesions intra-operatively.

Table 4: Associated Co-Morbidities

\begin{tabular}{|l|c|c|c|c|}
\hline Surgery & $\begin{array}{c}\text { Diabetes } \\
\text { Mellitus }\end{array}$ & Hypertension & $\begin{array}{c}\text { Diabetes } \\
\text { Mellitus }\end{array}$ & Hypertension \\
\hline Surgery & $\begin{array}{l}\text { Diabetes } \\
\text { Mellitus }\end{array}$ & Hypertension & $\begin{array}{c}\text { Diabetes } \\
\text { Mellitus }\end{array}$ & Hypertension \\
\hline Laparoscopic & 3 & 2 & 6.3 & 4.2 \\
\hline $\begin{array}{l}\text { Laparoscopic } \\
\text { converted to } \\
\text { open }\end{array}$ & 2 & 1 & 100 & 50 \\
\hline
\end{tabular}

Both cases were diabetic in the converted group as compared to none in the non converted group, 50 $\%$ were hypertensive's in the converted group as compared to $4.2 \%$ in the non converted group respectively.

Table 5: Ultrasonography

\begin{tabular}{|l|c|c|c|}
\hline Surgery & Ultrasound & Frequency & Percent \\
\hline \multirow{4}{*}{ Laparoscopic } & Multiple gall stones & 6 & 12.5 \\
\cline { 2 - 4 } & Acute cholecystitis & 16 & 33.3 \\
\cline { 2 - 4 } & Chronic cholecystitis & 26 & 54.2 \\
\hline \multirow{3}{*}{$\begin{array}{l}\text { Laparoscopic } \\
\text { converted to open }\end{array}$} & Total & 48 & 100 \\
\cline { 2 - 4 } & Acute cholecystitis & 1 & 50 \\
\cline { 2 - 4 } & Chronic cholecystitis & 1 & 50 \\
\cline { 2 - 4 } & Total & 2 & 100 \\
\hline
\end{tabular}

$6 \%$ of acute cholecystitis (1 of 17) needed conversion and $100 \%$ of those who showed a CBD calculus needed conversion.

\section{Conclusion}

In our study we concluded that

- In acute disease the chances rate of conversion is higher

- Presences of adhesions and inflammation intraoperatively is $s$ key factor, The rate of conversion and the bile stone spillage ids proportional to the severity of the disease.
- In acute cases the chances of perforation was around $80.5 \%$ and in chronic disease 13.75 percent

- The intraheaptic gall bladder,

- Those with short cystic duct and frozen Calots had a higher rate.

\section{References}

1. Stinton LM, Shaffer EA. Epidemiology of gallbladder disease: cholelithiasis and cancer. Gut and liver. 2012 Apr;6(2):172.

2. Hundal R, Shaffer EA. Gallbladder cancer: epidemiology and outcome. Clinical epidemiology. 2014;6:99.

3. Steiner CA, Bass EB, Talamini MA, Pitt HA, Steinberg EP. Surgical rates and operative mortality for open and laparoscopic cholecystectomy in Maryland. New England Journal of Medicine. 1994 Feb 10;330(6):403-8.

4. Parekh PM, Shah NJ, Suthar PP, Patel DH, Mehta C, Tadvi HD. Bacteriological analysis of bile in cholecystectomy patients. International Journal of Research in Medical Sciences. 2017 Jan 16;3(11):3091-6.

5. Livingston EH, Rege RV. A nationwide study of conversion from laparoscopic to open cholecystectomy. The American journal of surgery. 2004 Sep 1;188(3):20511.

6. Lo CM, Liu CL, Fan ST, Lai EC, Wong J. Prospective randomized study of early versus delayed laparoscopic cholecystectomy for acute cholecystitis. Annals of surgery. 1998 Apr;227(4):461.

7. Cuschieri A, Dubois F, Mouiel J, Mouret P, Becker H, Buess G, Trede M, Troidl H. The European experience with laparoscopic cholecystectomy. The American journal of surgery. 1991 Mar 1;161(3):385-7.

8. Csendes A, Navarrete $C$, Burdiles $P$, Yarmuch J. Treatment of common bile duct injuries during laparoscopic 
cholecystectomy: endoscopic and surgical management. World journal of surgery. 2001 Oct 1;25(10):1346-51.

9. Sakpal SV, Bindra SS, Chamberlain RS. Laparoscopic cholecystectomy conversion rates two decades later. JSLS: Journal of the Society of Laparoendoscopic Surgeons. 2010 Oct;14(4):476.

10. Ludwig K, Bernhardt J, Steffen H, Lorenz D. Contribution of intraoperative cholangiography to incidence and outcome of common bile duct injuries during laparoscopic cholecystectomy. Surgical endoscopy. 2002 Jul 1;16(7):1098-104.

11. Beal JM. Historical perspective of gall stone disease. Surg Gynecol Obstet 1984; 158:81.

12. Traverso LW.:Carl Langenbuch and the first cholecystectomy. Am J Surg. 1976 Jul;132(1):81-2.

13. Litynski GS. Erich Mühe and the rejection of laparoscopic cholecystectomy (1985): a surgeon ahead of his time. JSLS: Journal of the Society of Laparoendoscopic Surgeons. 1998 Oct;2(4):341.

14. Chalkoo M, Ahanger S. The Historical Perspective, Current Advancements and Innovations in Laparoscopic Cholecystectomy. J Pak Med Stud. 2012; 2(3):86-87.

15. Moore KL, Dalley AF, Agur AM. Clinically oriented anatomy. Lippincott Williams \& Wilkins; 2013 Feb 13.

16. Bismuth H. Surgical anatomy and anatomical surgery of the liver. world Journal of Surgery. 1982 Jan 1;6(1):3-9.

17. Suzuki M, Akaishi S, Rikiyama T, Naitoh T, Rahman MM, Matsuno S. Laparoscopic cholecystectomy, Calot's triangle, and variations in cystic arterial supply. Surgical endoscopy. 2000 Feb 21;14(2):141-4.
18. Michels NA. Newer anatomy of the liver and its variant blood supply and collateral circulation. The American Journal of Surgery. 1966 Sep 1;112(3):337-47.

19. Daniels BT, McGlone FB, Job H, Sawyer RB. Changing concepts of common bile duct anatomy and physiology. JAMA. 1961 Oct 28;178(4):394-7.

20. Everson GT. Gallbladder function in gallstone disease. Gastroenterol Clin North Am 1991;20:85-110.

21. Njeze GE. Gallstones. Nigerian Journal of Surgery. 2013;19(2):49-55.

22. Behar J. Physiology and pathophysiology of the biliary tract: The gallbladder and sphincter of Oddi-A review. ISRN Physiology. 2013 Feb 24;2013.

23. Afdhal NH. Diseases of the Gallbladder and Bile Ducts. In: Goldman L, Ausiello D. (eds.). Cecil Textbook of Medicine. 23rd ed. Philadelphia, Pa: Saunders Elsevier; 2007:65-78

24. Thompson. Laparoscopic Cholecystectomy, Intraoperative Cholangiography and Common Bile Duct Exploration. In, Josef E. Fisher (ed), Mastery of Surgery Volume $1,5^{\text {th }}$ edition. Wolters Kluwer Publishers, 2007; 111628.

25. Mills JC, Stappenbeck TS, Bunnett NW. Gastrointestinal disease. In: McPhee SJ, Hammer GD, eds.Pathophysiology of Disease: An Introduction to Clinical Medicine. 6th ed. New York, NY: McGraw-Hill Medical; 2010. 